Competency-Based Talent Management: Three Perspectives in an Academic Library Lorelei Rutledge, The University of Utah Sarah LeMire, Texas A\&M University Melanie Hawks, The University of Utah Alfred Mowdood, The University of Utah 
Abstract: This article describes how the University of Utah’s J. Willard Marriott Library implemented a competency-based, talent management system across the organization management system across the organization process to address organizational, departmental, and individual needs. Success of the implementation was mixed. Designing human resources systems around core competencies made organizational values and goals concrete but proved unsustainable in the long-term. Using core competencies to shape departmental goals, coach staff and library faculty, and onboard new employees proved beneficial at the middle management level.

Keywords: competencies, talent management, middle managers, faculty development, job descriptions,

Author's Note: Address correspondence to: Lorelei Rutledge, Faculty Services Librarian, University of Utah, J. Willard Marriott Library, 295 S. 1500 E. Salt Lake City, UT, 84112-0860, USA. E-mail: lorelei.rutledge@utah.edu; Sarah LeMire, First Year Experience \& Outreach Librarian, Texas A\&M University Libraries, 5000 TAMU, College Station, TX 77843, USA. Email: slemire@library.tamu.edu; Melanie Hawks, Human Resources Learning and Development Manager, University of Utah, J. Willard Marriott Library, 295 S. 1500 E. Salt Lake City, UT, 84112-0860, USA. E-mail: melanie.hawks@utah.edu; Alfred Mowdood, Head of Faculty Services, University of Utah, J. Willard Marriott Library, 295 S. 1500 E. Salt Lake City, UT, 84112-0860, USA. E-mail: alfred.mowdood@utah.edu

Received: August 5, 2015

Accepted: September 18, 2015 


\section{Competency-Based Talent Management: Three Perspectives in an Academic Library}

Given limited resources, how can libraries ensure that employees have the necessary skills and attributes to best meet library objectives? One strategy for ensuring this alignment between individual performance and library needs is using core competencies. Core competencies, which include knowledge, skills, attitudes and personal attributes that enable people to succeed in a given environment, enable libraries to recruit employees who have the capacity to meet the library's current needs as well as the ability to adapt to meet future needs. Using core competencies throughout the talent management process enables middle managers and human resources administrators to help library employees maximize their potential. In this paper, we describe a competency-based talent management approach from the perspective of an HR manager, two middle managers, and a new librarian. Our experiences illustrate an academic library can use core competencies to improve employee performance; they also show some of the limitations of using core competencies as part of a talent management system.

\section{Literature Review}

Using core competencies to measure performance developed as an innovation from earlier assumptions that intelligence test scores predicted career success, a position disproven by McClelland's work in the 1970s (McClelland, 1973, 1998). Pralahad and Hamel (1990) were the first to develop the concept of core competencies in organizations and defined core competencies as "the collective learning in the organization, especially how to co-ordinate diverse production skills and integrate multiple streams of technologies” (p. 81). The Association of Research Libraries (ARL) SPEC kit survey in 2002 identified 17 ARL libraries using competencies and a subsequent SPEC kit survey in 2014 identified 31 ARL libraries using core competencies (McNeil, 2002; Taylor \& Lee, 2014, p. 14). Since 2010, competency 
documents from various library groups and organizations have proliferated [Canadian Association of Research Libraries (CARL), 2010; Library of Congress, 2011; Reference \& User Services Association (RUSA), 2013; North American Serials Interest Group (NASIG), 2013]. The American Library Association has published guidelines for performance that incorporate core competences in areas such as reference work and liaison relationships in collection development (American Library Association, 2001, 2004).

Since the 1990s, competency models have been used frequently in human resources and serve as the underpinnings of talent management. Competencies are "the building blocks of a talent management system” (Berger \& Berger, 2011, p. 7). Talent management is defined as "an integrated set of processes, programs, and cultural norms in an organization designed and implemented to attract, develop, deploy, and retain talent to achieve strategic objectives and meet future business needs” (Silzer \& Dowell, 2010, p. 18). Talent-management activities include "recruitment and hiring, retention, employee engagement, job classification management, compensation management, performance assessment, competencies, professional development planning, and succession planning” (Taylor \& Lee, 2014, p. 9). Taken together, these activities create a system in which needs, values, expectations, performance, and rewards are aligned. Competencies are integral to talent management because they serve as a consistent, objective basis for making decisions about hiring, promoting, evaluating, and developing employees. They also signal organizational values and convey expectations about performance standards. According to SPEC Kit 344 Talent Management, ARL libraries are incorporating competencies into their position descriptions, performance evaluations, training and development activities, and recruitment efforts (Taylor \& Lee, 2014). 
The term "competencies" is often used interchangeably in the library literature with knowledge, skills, and abilities, or attributes (KSAs) (Chan, 2014; Giesecke \& McNeil, 1999; Crowe \& Jaguszewski, 2011). Indeed, some librarians define competencies specifically as KSAs, including Soutter (2013), who notes that "competency, for the purposes of this research study, was defined as reframing work by deconstructing positions or jobs and rephrasing their content as components or elements, typically as knowledge (cognitive), skills (functional), and attitudes (behavioral), with an eye to those that determine success. This success was dependent on the ability to learn how to learn: 'meta-competence’” (p. 6). While this definition captures several elements that comprise a competency, other literature draws an important distinction between competencies and KSAs. Singer and Griffith (2010) explain that "competencies and KSAs are related, but competencies go beyond the KSAs required for any individual job. They add, sometimes implicitly, the attitudes and values that are the foundation for behavior and performance” (p. 29). Core competencies incorporate the knowledge, skills, abilities, attitudes, and values that an employee needs to successfully perform his or her job at present and also in the future (Berger \& Berger, 2011, p. 7).

Many libraries have developed their own competencies to hire, assess, and evaluate librarians. Soutter (2013) notes that "competencies describe requirements for positions in an attempt to improve human performance” (p. 2). Singer and Griffiths (2010) suggest that "competencies can be at the center of many of your human resource policies and programs as they specify performance management criteria, help plan careers, and highlight training and development needs, to name a few” (p. 30). Other organizations have used core competencies in times of change to assess training needs and establish performance expectations. Chamberlain and Reece (2014) describe using core competencies after a reorganization to choose which 
current employees would join a new e-resources unit and to determine areas of growth for unit members moving forward. Sullenger (2014) recounts using them similarly to map the duties required of e-resources librarians in her department. Robinson, Runcie, Manassi, and MckoyJohnson (2015) describe the process of identifying and formulating the required competencies of librarians at the University of the West Indies’ Mona Library in order to align these objectives with a broader UWI competency framework. Thomas and Patel (2008) illustrate the need for competency-based training for digital librarians, which relies on defining competencies for positions in order to develop training.

\section{Different Perspectives on Core Competencies}

Although a number of libraries have written about their experiences implementing core competencies, the authors of many of these articles hold senior or administrative positions, and their articles are aimed at librarians in leadership or management roles (Huff-Eibl, Voyles \& Brewer, 2011; Dole, 2013; Goetsch, 2008; McCleskey, 2003). In this article, we will discuss the implementation of core competencies in job descriptions, performance evaluations, and training and development from the perspectives of a variety of individuals affected by competencies, including a member of library human resources, a faculty middle manager, a staff supervisor who later returned as a librarian, and an early career librarian new to the organization. These perspectives reveal how the benefits and challenges of implementing core competencies resonate throughout an organization and suggest that core competencies is a topic relevant to employees at all levels within library organizations. In the next section of the article, Melanie Hawks will discuss how the library's human resources division attempted to implement a competency-based talent-management system across the organization. Sarah LeMire, a staff supervisor at the time competencies were introduced, will then describe the challenges she faced 
as she worked with her employees to evaluate their skills and plan opportunities for further growth and development. Alfred Mowdood will discuss how implementing core competencies as the head of a department enabled him to hire employees who were a good fit for the department, encourage current employees to take on new challenges and learn new skills to better meet the library's needs, provide yearly evaluations that engaged employees in managing their own professional development, and offer regular training opportunities to help employees meet core competencies more effectively. Finally, Lorelei Rutledge, a new librarian, will discuss her experience coming into Alfred's department and how core competencies helped her meet performance expectations and manage her own professional development.

\section{Core Competencies from the Human Resources Perspective (Melanie Hawks)}

The Marriott Library’s documented interest in competencies dates back to its 2004-08 strategic plan. "Define core competencies for all staff” appears as the first goal under the broader objective, "Improve knowledge of, familiarity with, and comfort with library processes and technology" (J. Willard Marriott Library, 2004, para. 62). Internal documents from this time period indicate that competencies were viewed as a way to identify, describe, and hold people accountable for meeting the expectations associated with changes in the profession, technology, and organization. From 2005-08, the library undertook a "transformation" that included an $\$ 80$ million building renovation, a reorganization, and coordinated planning processes around new roles and services. In August 2007, a New Roles Task Force was charged with "consider[ing] the changing roles of staff and librarians in light of the reorganization; the new building; and the discipline-wide changes in library technology and practices” (J. Willard Marriott Library, 2007d, para. 1). In October 2007, consultants Maureen Sullivan and Shelley Phipps conducted a 3 day site visit intended to help everyone in the library envision the library's future. One of the 
stated goals of that visit was to "Identify the new competencies for staff and librarians" (J. Willard Marriott Library, 2007a, para. 4). Following this visit, the New Roles Task Force formed a behavioral standards subgroup whose job was to "identify expectations for all employees; technical competencies for employees, and specific competencies for work groups” (J. Willard Marriott Library, 2007b, para. 2).

The first draft of what would become the library’s Organization-Wide Competencies document was titled “Marriott Library Behavioral Standards,” which suggests that competencies (at least during this stage) were primarily seen as a way to govern individual behavior, and not necessarily as the “fundamental underpinnings of H[uman] R[esources] systems” (Dalziel, 2011, p. 21). The task force developed the competencies, issued its report, and then adjourned; implementation beyond this was delegated to the library’s human resources division. The final draft of the task force’s document was titled “Organization-Wide Competencies” and included an introductory paragraph stating: "Marriott Library is committed to its employees and will provide guidance and training to help them achieve success in the three competency areas. The Library supports and rewards continuous learning and training” (J. Willard Marriott Library, 2007c, para. 1). The three competency areas--Patron Focus, Effectiveness, and Communication-and their behavioral standards became the foundation for the library’s talent management activities over the next 4 years, carried out primarily by the human resources division. In line with the stated commitment to continuous learning and training, the library hired me as the Learning and Development Manager in April 2008.

Soon thereafter in 2008, the library’s human resources division was charged with creating new position descriptions for all full-time employees (faculty and staff). The reorganization had changed reporting structures, job titles, and work duties significantly enough 
to warrant a complete restart; over a period of about a year, every employee rewrote (or wrote) his or her job description, with training and assistance provided by me and final approval given by senior managers. The position description template included a section for "Position-Specific Competencies,” as the New Roles Task Force had intended. Because these competencies had not yet been defined, and because we needed new position descriptions urgently, the library’s executive council decided to leave that section of the template blank temporarily. The template included a section headed “Organization-Wide Competencies” with the following language: “All employees of the Marriott Library are accountable for meeting the expectations found at: https://jobs.tools.lib.utah.edu/JobPDF/OrganizationWideCompetencies.pdf”' (J. Willard Marriott Library, 2008, para. 1).

These changes set the stage for incorporating the competencies into two other human resources areas: performance evaluation and training and development. In early 2009, we rolled out a new performance evaluation process and form that included an assessment of each employee’s self-perceived ability to meet the organization-wide competencies. This was intended as a baseline measure to determine whether employees (1) understood the competencies in relation to their work and (2) believed they had the skills and tools necessary to meet the competencies. The purpose of this baseline measure was to help employees set developmental goals for the upcoming year and to enable human resources to prioritize training activities. Based on the results of these assessments, we delivered training aligned with the following competency-based standards in 2009: “Understands the library’s collections and core systems” (Introduction to Library Collections; SharePoint Basics; CONTENTdm); "Plans and organizes well by managing time and priorities to accomplish tasks” (Time Management; 
Meeting Management); "Listens effectively and transmits information clearly and accurately" (Workplace Writing Skills; Presentation Skills) ( J. Willard Marriott Library, 2007c, para. 1).

The new position descriptions, which were completed in spring 2009, enabled us to take a new approach to performance evaluation. For several years up to 2009, the evaluation form asked employees to assess progress on their previous year's goals, list major accomplishments, identify developmental needs, and create goals for the upcoming year. Beginning in early 2010 (for the Jan. 1-Dec. 31, 2009 year), employees were asked to assess their strengths and identify areas for improvement for the major duties listed in their position descriptions. They were also asked to indicate whether each of the bullet points listed under the organization-wide competencies was an area of strength, an area of competence, or an area for improvement. We realized that people would define these measures differently, so we attempted to standardize the definitions in order to give both supervisors and employees some guidelines. However, because employees felt strongly that the specific expectations for meeting the standards should vary according to the person's role (e.g., a librarian working in the Knowledge Commons should be held to a higher standard of "Understand[ing] the library's collections and core systems" than an accountant working in Financial Management), we lacked any objective, consistent measure. As a result, employees and supervisors had to determine for themselves whether the expectations were being met, which sometimes led to disagreement and conflict.

Employees also completed an annual learning plan as part of the evaluation. This plan enabled them to set concrete development goals around the areas for improvement in both their job assessment and organizational competencies assessment. It also enabled human resources to create a year-long organizational training and development plan. With the support of the executive council, we designated a 2-hour weekly block as "dedicated training time," with one 
session per month devoted to training on skills related to standards in the organizational competencies. In 2010, these training topics included EndNote, RefTracker, Primo/Aleph, time management, SharePoint, MS Word, Outlook, and e-books. We also devoted one session per month to supervisory or management training, with a focus on performance management; the purpose of these trainings was to give supervisors the tools they needed to deal with the kinds of issues and questions that had emerged during the rollout of the 2010 performance evaluation. Trainings offered included Setting Clear Expectations, Performance Conversations, Supporting High Performers, Developing Middle Performers, and Holding Low Performers Accountable. As part of a new onboarding program, we also directed supervisors to review the position description, job expectations, and organizational competencies with each new employee during the first week.

From a human resources perspective, the set of processes, activities, and documents described above seemed like a solid approach to integrating competencies into the regular workflow and the organizational culture--thus creating a competency-based talent management system that worked at both the organizational level and the local level. By late 2012, however, it was clear that we had not achieved the degree of adoption and buy-in necessary to effect largescale change (Forman, 2011). Employees at all levels of the organization found the evaluation process cumbersome, especially because it required completing three separate forms. Without a formal and consistent mechanism for rewarding high performance, we could not reinforce positive behavior (i.e., meeting the standards associated with the competencies). Over time, interest in and energy for competency-based performance planning and management waned. The position-specific competencies were never defined. The performance evaluation process and forms were revised and simplified--employees were asked to evaluate their performance 
considering the duties in their job descriptions and the organizational competencies but were no longer held directly and specifically accountable for each. In 2015, the position description template was revised to delete references to both position-specific and organizational competencies. These actions were in part the result of conscious decisions to focus less on creating and sustaining complex internal systems. The amount of time and effort required to identify competencies and behavioral standards, provide the necessary training for all employees, develop consistent yet flexible evaluation and planning tools, and ensure that dozens of different supervisors implemented a similar set of practices simply proved more than the organization was willing and able to do in light of competing priorities.

Despite these limitations with implementation at the organization-wide level, the processes and structures we created had an impact at the individual and departmental level. Our experience with core competencies at these levels demonstrates the potential and advantages of leadership from the middle as well as the challenges.

\section{Core Competencies from a Middle-Management Perspective}

Over the last decade, the phrase "leading from the middle” has become common parlance in management and leadership scholarship and practice as well as in libraries. Books

and articles on the subject abound (Cawthorne, 2010; Ebbers, Conover, \& Samuels, 2010; Stone \& Coussons-Read 2011; Turner, 2007); the Chicago Library System sponsored a Leading from the Middle workshop series in 2006; ACRL/LAMA jointly sponsored a Spring Virtual Institute titled “Leading from the Middle: Managing in All Directions.” Oshry (1994) was one of the first to articulate the unique challenges and opportunities of those occupying the middle space within an organization. Positioned between administrators with the authority to devise organizational strategy and front-line employees with the responsibility for implementation, middles possess 
“integrating” power (Oshry, n.d., Total System Power). By sharing/analyzing information and coordinating efforts amongst themselves and between the two other groups, middles strengthen the organization's capacity (Oshry, 1994). However, the middle group’s effectiveness is hindered by the "tearing” sensation they feel when trying to satisfy conflicting needs from administrators, employees, and peers (Oshry, 1994). Leading from the middle requires sensitivity to institutional politics, a collaborative (rather than competitive) mindset, rigorous problem-solving, and the courage to "go first" when others may be skeptical, paralyzed, or hedging. Middle managers are "vital catalysts for identifying, developing, and implementing competencies” (King, Fowler, \& Zeithaml, 2001, p. 98) because they have insights into both overall organizational strategy and the strengths and gaps in employee knowledge, skills, and abilities.

The implementation of competency-based talent management in our library yielded two examples of middle leadership that will be described as first-person accounts in the next two sections of this paper. The first section describes the experiences of Sarah LeMire, then the Institutional Repository Coordinator; the second describes the experiences of Alfred Mowdood, who was then the Head of Research and Information Services.

\section{Core Competencies from the Staff Supervisor Perspective (Sarah LeMire)}

From the perspective of a new staff supervisor simultaneously striving to learn about and implement core competencies, incorporating competencies required surmounting some significant challenges. Because organization-wide competencies were initially implemented as an element of the annual performance evaluation process, some library staff members were reluctant to identify competencies as areas for improvement, perhaps out of concern that articulated areas of weakness might be held against them when evaluations were used to 
determine merit-based pay raises in the future. Also, it was difficult for some employees to rate themselves accurately, since they might know how to use a particular tool to perform a specific task, but not recognize the limited nature of their skills or understand that their ability to use that tool in new ways or to solve other organizational problems might be limited or nonexistent. These factors may explain why some employees consistently demonstrated overconfidence in their skill sets, ranking their proficiency with different tools and techniques as areas of strength, even when that rating was not the most appropriate. In this sense, my experience reflected the finding that "research consistently demonstrates that individuals are notoriously inaccurate in assessing their own performance, and the poorer the performer, the higher (and more inaccurate) the self-assessment” (Grote, 2011, p. 54).

As a staff supervisor, I was tasked with discussing organizational competencies with my direct reports and having open and honest conversations with these employees about differences between the employee's and my rating of the employee’s competencies. These conversations, although sometimes challenging, were an opportunity to reassure employees and examine their individual growth potential. Through this process, employees were able to articulate the areas that they were interested in developing new skills, and supervisors were able to connect employees with training opportunities offered by the library, including training in specific software such as Microsoft Outlook.

\section{Core Competencies from the Department Head Perspective (Alfred Mowdood)}

I experienced both the benefits and challenges of using core competencies at the departmental level as Head of Research and Information Services (RIS). Although the library has since reorganized departments, RIS was a department of 11 faculty librarians charged with providing reference and instruction as well as collection-development support across campus. 
After the library's reorganization in 2008, focusing on core competencies in job descriptions enabled us to better recruit new faculty who could meet the needs of the department. Core competencies also enabled our department of middle- and late-career librarians, most of whom had over 20 years of experience in academic librarianship, to adapt and evolve to meet the needs of $21^{\text {st }}$-century researchers. Based on our discussions of how the core competencies related to their work, these librarians realized that they needed to devote more time and effort to active outreach (meeting and working with faculty in their offices), creating digital learning objects, and meeting with student groups working on capstone, research, or business competition projects.

The use of core competencies improved my department's hiring practices. We created job advertisements that listed required core competencies for new librarians, making the organization's needs and expectations clear in every job advertisement. One job advertisement had a bulleted list of required qualifications including a number competency-based requirements such as: "Demonstrated commitment to providing and assessing user-centered library services; Strong commitment to and demonstrated skills in teaching that uses innovative and engaging pedagogical strategies; Excellent communication skills, both oral and written; strong interpersonal skills; ability to work effectively in a team environment and independently, and to work collaboratively with campus partners” (J. Willard Marriott Library, 2011, para. 2). In our department, we have had two successful searches to hire librarians. Further, using competencies also enabled our new librarians to highlight their technology skills and expertise with new tools and provide help to librarians not as adept at new technologies.

Clear job descriptions also improved management and evaluation for current library employees as well. After we revised job descriptions to incorporate core competencies, I met at 
least annually with each librarian in my department to discuss whether their job description still reflected their current work and evaluate their ability to meet the core competencies required. These discussions offered useful opportunities for feedback and enabled me to provide longerterm support for training, growth, and new responsibilities for librarians at any stage of their career. With several service points eliminated or consolidated in the reorganization, longserving library staff in my department seized new opportunities to take on leadership roles in supporting grant-writing and grant-seeking, conducting cross-disciplinary research, offering online reference services and patent-searching education, and offering outreach to underrepresented groups on campus. These activities demonstrated the competencies of accepting new challenges and changes in direction, and communicating constructively and respectfully (J. Willard Marriott Library, 2009).

Core competencies also played a key role in performance evaluation. For 3 years, I had in-depth discussions about core competencies during each librarian's annual review. In the first year, we ranked librarians in 19 areas of competency, such as "understands and meets the needs of patrons and addresses their interests and concerns in a timely and professional manner; Understands the organizational structure of the library; seeks to achieve results across disciplines, departments, and functions” (J. Willard Marriott Library, 2009, para. 2). Even though people complained about the number of criteria, it was helpful for individual conversations with librarians. In the second and third years, nine criteria were evaluated, in a more streamlined, but still valuable process. Having set criteria helped me make sure I was on the same page with each employee during each evaluation and enabled detailed conversations about the highest priority criteria. 
Core competencies also helped shape the entire library’s learning plan and helped me work with my staff to identify areas for further professional development and education, tied directly to the expectations of the organization. Discussing core competencies with senior librarians enabled many of them to see areas where they needed additional training to better support their changing roles. Once they saw these needs, I was able to work with them to create professional development plans to help them reach their goals. The discussion of core competencies within the RIS group led to the realization that we needed to better articulate best practices for service at the reference desk as well as when helping patrons during online and phone reference transactions so that we knew what meeting each competency would look like. The best practices we defined were approved by the library administration to become part of the organization's official set of policies, guidelines, and forms. The work my employees and I did also had direct benefits for the library, helping library administration to better quantify and measure expectations for librarians, highlighting and prioritizing the work that directly relates to the library's mission.

As both Sarah's and Alfred's experiences demonstrate, competencies gave middle managers a clear sense of how they could play the integrator role between the library's administration and their employees. By aligning departmental practices with organizational goals, middle managers facilitated communication, clarified expectations, and advocated for change. Middle managers did experience some of the conflict and ambiguity typical in the integrator role as they attempted to implement new practices at a local level, especially since such implementation was not consistent from department to department. In the following section, a new librarian who reported to Alfred Mowdood in Research and Information Services will describe her experiences being on the receiving end of competency-based management. 


\section{Core Competencies from the New Librarian Perspective (Lorelei Rutledge)}

As a new librarian, I benefited from having core competencies embedded in my job description. Having specific competencies named, such as skill in a variety of teaching and learning technologies, enabled me to start a conversation with my supervisor about which skills I already had and how I could deploy them effectively. Likewise, having competencies written into my job description helped me think about which competencies the organization found most useful in my position and how I could continue developing them.

During my first year at the library, I was required to complete an annual review with my supervisor, and the core competencies in my job description helped during that process. Since I knew from the first day on the job which competencies were highlighted in my job description, I made sure to keep track of how I developed those skills. When I had my annual review, I was able to point to specific times when I had used and developed those competencies. The job description and the included competencies were especially helpful during my informal tenure reviews. The Marriott Library’s tenure criteria are deliberately open-ended in order to encompass the work of librarians with different areas of expertise. However, having core competencies available allowed me to further focus my descriptions of my achievements. For instance, because one of the core competencies included being able to use and teach a variety of bibliographic management software, I was able to describe and show evidence of my continued development of classes to teach these tools.

Core competencies were also helpful to me in working with my supervisor to develop a professional development plan. By looking at the required core competencies, I was able to see areas for further development and find opportunities to develop those skills. When I knew that I would be taking on a supervisory role, for instance, I was able to develop a plan with my 
supervisor to sharpen my skills. Having core competencies enabled me to align my professional goals with the needs of the organization and offered much-needed clarity in helping me determine which professional development opportunities and new projects would be most beneficial to pursue.

\section{Conclusion}

The Marriott Library's implementation of core competencies as part of a talent management process affected employees at all echelons of the library and was perceived very differently based upon the individual's perspective. From the human resources perspective, core competencies presented an exciting opportunity to tie several processes together into a cohesive talent management system. However, competencies proved very difficult to incorporate across the institution without significant administrative support and commitment to long-term sustainability. The enthusiasm employees from all levels of the organization initially felt about competencies during the library transformation waned as the reality of competency-based management set in and as new priorities for their time and attention emerged. Although librarians and supervisors felt the practical challenges of implementing core competencies at the individual and department level, they also found that competencies can be a helpful tool for talent management. Competencies are especially useful for recruitment and retention since they can help orient employees and potential employees toward individual, department, and librarywide goals. Managers and supervisors also found that core competencies embedded in the evaluation process can serve as a springboard to productive conversations that orient employees to the future, rather than just their current responsibilities. Competencies can provide a framework for middle managers as they strive to meet the larger administrative goals for the 
library, while also providing support and encouragement for individuals. And for new employees, competencies can assist in orienting them to department goals and library strategic priorities, while also helping them identify new skills that they can acquire to meet those goals. 


\section{References}

American Library Association. (2004). Guidelines for behavioral performance of reference and information service providers. Retrieved from http://www.ala.org/rusa/resources/guidelines/guidelinesbehavioral

American Library Association. (2001). Guidelines for liaison work in managing collections and services. Retrieved from http://www.ala.org/ala/rusa/rusaprotools/referenceguide/guidelinesliaison.htm

Berger, L.A., \& Berger, D. R. (2011). Designing and assembling the building blocks for organization excellence: The talent management model. In L. Berger \& D. Berger (Eds.), The talent management handbook: Creating a sustainable competitive advantage by selecting, developing, and promoting the best people (2nd ed.). New York, NY: McGraw-Hill.

Canadian Association of Research Libraries (CARL). (2010, October). Core competencies for $21^{\text {st }}$ century CARL librarians. Retrieved from http://carl-abrc.ca/uploads/pdfs/core_comp_profile-e.pdf

Cawthorne, J. E. (2010). Leading from the middle of the organization: An examination of shared leadership in academic libraries. The Journal of Academic Librarianship, 36(2), 151-157. doi:10.1016/j.acalib.2010.01.006 
Chamberlain, C., \& Reece, D. (2014). Library reorganization, chaos, and using the core competencies as a guide. Serials Librarian, 66, 248-252. doi:10.1080/0361526X.2014.881162

Chan, E. K. (2014). Analyzing recorded transactions to extrapolate the required knowledge, skills, and abilities of reference desk providers at an urban, academic/public library. Journal of Library Administration, 54(1), 23-32. doi:10.1080/01930826.2014.893113

Crowe, S.H. \& Jaguszewski, J.M. (2011). Preparing our librarians for the future: Identifying and assessing core competencies at the University of Minnesota libraries. In Walter, S., \& Williams, K. (Eds.), The expert library: Staffing, sustaining, and advancing the academic library in the 21st century (pp. 127-157). Chicago, IL: Association of College and Research Libraries.

Dalziel, M. M. (2011). Formulating competencies. In L. Berger \& D. Berger (Eds.), The talent management handbook: Creating a sustainable competitive advantage by selecting, developing, and promoting the best people (2nd ed., pp. 13-21.) New York, NY: McGraw-Hill.

Dole, W.V. (2013). What's all this I hear about core competencies for library planning and assessment? Journal of Library Administration, 53(7-8), 472-481.

doi: 10.1080/01930826.2013.882201

Ebbers, L., Conover, K. S., \& Samuels, A. (2010). Leading from the middle: Preparing leaders for new roles. New Directions for Community Colleges, 2010 (149), 59-64. doi:10.1002/cc.396 
Forman, D. (2011). Establishing a talent management culture. In L. Berger \& D. Berger (Eds.), The talent management handbook: Creating a sustainable competitive advantage by selecting, developing, and promoting the best people (2nd ed., pp. 305-314). New York, NY: McGraw-Hill.

Giesecke, J., \& McNeil, B. (1999). Core competencies and the learning organization. Library Administration \& Management, 13(3), 158-166. Retrieved from http://digitalcommons.unl.edu/libraryscience/60

Goetsch, L. A. (2008). Reinventing our work: New and emerging roles for academic librarians. Journal of Library Administration, 48(2), 157-182. doi: 10.1080/01930820802231351

Grote, D. (2011). Designing a performance appraisal for driving organization success. In L. Berger \& D. Berger (Eds.), The talent management handbook: Creating a sustainable competitive advantage by selecting, developing, and promoting the best people (2nd ed., pp. 45-54). New York, NY: McGraw-Hill.

Huff-Eibl, R., Voyles, J. F., \& Brewer, M. M. (2011). Competency-based hiring, job description, and performance goals: The value of an integrated system. Journal of Library Administration, 51(7-8), 673-691. doi: 10.1080/01930826.2011.601270

J. Willard Marriott Library (2004, June 3). Five-year strategic plan: 2004-2008, draft. Unpublished internal document.

J. Willard Marriott Library (2007a). Consultation visit October 1-3, 2007. Unpublished internal document. 
J. Willard Marriott Library. (2007b, November 8). Marriott Advisory Council minutes. Unpublished internal document.

J. Willard Marriott Library. (2007c, December 17). Marriott Library organization-wide competencies. Unpublished internal document.

J. Willard Marriott Library. (2007d, December). New roles task force: Summary report. Unpublished internal document.

J. Willard Marriott Library. (2008). Job description template. Unpublished internal document.

J. Willard Marriott Library. (2009, February 2). Marriott Library organization-wide competencies. Retrieved from https://jobs.tools.lib.utah.edu/JobPDF/OrganizationWideCompetencies.pdf

J. Willard Marriott Library. (2011). Research and Information Services librarian [job posting]. Copy in possession of author.

King, A. W., Fowler, S. W., \& Zeithaml, C. P. (2001). Managing organizational competencies for competitive advantage: The middle-management edge. Academy of Management Perspectives, 15(2), 95-106. doi: 10.5465/AME.2001.4614966

Library of Congress. (2011). FLICC competencies for federal librarians. Retrieved from http://loc.gov/flicc/publications/Lib_Compt/2011/2011Competencies.pdf

McClelland, D. C. (1973). Testing for competence rather than for "intelligence.” American Psychologist, 28(1), 1-14. doi:10.1037/h0034092 
McClelland, D. C. (1998). Identifying competencies with behavioral-event interviews. Psychological Science, 9(5), 331-339. doi: 10.1111/1467-9280.00065

McCleskey, S. E. (2003). Staffing standards and core competencies in academic art and architecture departmental libraries: A preliminary study. Journal of Library Administration, 39(1), 1-21. doi: 10.1300/J111v39n01_01

McNeil, B. (2002). Core competencies. SPEC kit 270. Washington, DC: Association of Research Libraries Office of Leadership and Management Services.

North American Serials Interest Group (NASIG). (2013). NASIG core competencies for electronic resources librarians. Retrieved from http://www.nasig.org/uploaded_files/92/files/CoreComp/CompetenciesforERLibrarians_ final_ver_2013-7-22.pdf

Oshry, B. (1994). In the middle. Boston, MA: Power and Systems.

Oshry, B. (n.d.) Total system power: Developers, fixers, integrators, and validators. Retrieved from http://powerandsystems.com/files/downloads/Total\%20System\%20Power.pdf

Prahalad, C. K., \& Hamel, G. (1990). The core competence of the corporation. Harvard Business Review, 68(3), 79-91. Retrieved from https://hbr.org/magazine

Reference \& User Services Association (RUSA). (2013). Guidelines for behavioral performance of reference and information service providers. Retrieved from http://www.ala.org/rusa/resources/guidelines/guidelinesbehavioral 
Robinson, K. P., Runcie, R., Manassi, T. M., \& Mckoy-Johnson, F. (2015). Establishing a competencies framework for a Caribbean academic library: The case of the UWI library, Mona campus. Library Management, 36(1/2), 23-39. doi:10.1108/LM-10-2014-0123

Silzer, R. F., \& Dowell, B. E. (2010). Strategy-driven talent management: A leadership imperative. San Francisco, CA: Jossey-Bass.

Singer, P. M., \& Griffith, G. (2010). Succession planning in the library: Developing leaders, managing change. Chicago, IL: American Library Association.

Soutter, J. L. (2013). Academic librarian competency as defined in the Library and Information Science Journal Literature of 2001-2005 and 2011. Partnership: The Canadian Journal of Library \& Information Practice \& Research, 8(1), 1-19. Retrieved from http://condor.lib.uoguelph.ca/index.php/perj/article/view/1991

Stone, T. \& Coussons-Read, M. (2011). Leading from the middle: A case-study approach to academic leadership for associate deans. Lanham, MD: Rowman \& Littlefield.

Sullenger, P. (2014). A departmental assessment using the core competencies for electronic resources librarians. Serials Review, 40(2), 88-96. doi:10.1080/00987913.2014.922377

Taylor, M.A., \& Lee, E. (2014). Talent management. SPEC kit 344. Washington, DC: Association of Research Libraries.

Thomas, C., \& Patel, S. I. (2008). Competency-based training for digital librarians: A viable strategy for an evolving workforce? Journal of Education for Library and Information Science, 49(4), 298-309. Retrieved from http://www.jstor.org/stable/40323757 
Turner, C. (2007). Leading from the middle: Dealing with diversity and complexity. School Leadership \& Management, 27(5), 401-403. doi: 10.1080/13632430701606038 